\title{
Adrenocorticotropin-Independent Macronodular Adrenocortical Hyperplasia Associated with Multiple Colon Adenomas/Carcinomas Which Showed a Point Mutation in the $A P C$ Gene
}

\author{
Noriyoshi Yamakita, Toshihiro Murai, Yasufumi Ito, Kiyoshi Miura*, Tsuneko IkedA**, \\ Kohji MiYамото***, Shumpei ONAMI**** and Teruhiko YoshidA****
}

We report a male Japanese with corticotropin (ACTH)-independent macronodular adrenocortical hyperplasia (AIMAH) associated with multiple colon adenomas/carcinomas. The plasma cortisol level was elevated with no diurnal rhythm and was not suppressed with dexamethasone. Basal plasma ACTH was unmeasurable but subnormally increased after administration of metyrapone or corticotropin releasing hormone. Both adrenals were resected and weighed $90 \mathrm{~g}$; the histopathologic findings were similar to those of AIMAH as previously reported. At least 21 colon lesions which were adenomas or carcinomas, were resected endoscopically or surgically. This is the second reported case of the association of AIMAH with multiple colon polyps. An APC gene point mutation was detected in the colon cancer tissue by polymerase chain reaction (PCR)-single strand conformation polymorphism (SSCP)/direct sequencing analysis at the putative splice acceptor site consensus sequence. However, no abnormality of $A P C$ gene was detected in the adrenocortical hyperplastic tissue. The possible etiological coexistence of these two diseases is discussed.

(Internal Medicine 36: 536-542, 1997)

Key words: Cushing's syndrome, adrenocortical nodular hyperplasia

\section{Introduction}

Nodular adrenocortical hyperplasia is not common for the etiology of Cushing's syndrome and consists of a few clinicopathological types. However, its classification has not been well defined. The clinical and pathological entity of primary pigmented adrenocortical micronodular dysplasia (PPAMD) has been established (1). Although the clinical and pathological characteristics of some cases of macronodular adrenocortical hyperplasia have become clear, their etiology has not been clarified yet. One such hyperplasia was presented as corticotropin (ACTH)-independent bilateral macronodular adrenocortical hyperplasia (AIMAH) by Aiba et al (2). We report a patient with AIMAH who was associated with multiple colon polyps; the association is extremely rare. We tried to clarify the etiological possibility of this coincidence in our patient.

For editorial comment, see p 533.

\section{Materials and Methods}

All blood samplings were performed after at least one hour of bed rest.

\section{Hormone measurement}

Plasma cortisol and dehydroepiandrosterone were measured by Gammacort Cortisol Kit ${ }^{\mathrm{TM}}$ (Baxter-Travenol) (reference range, $110-505 \mathrm{nmol} / l)$ and COAT-A-COUNT DHEA ${ }^{\mathrm{TM}}(\mathrm{Di}-$ agnostic Product Co., Los Angeles, CA, USA) (2.8-24.3 nmol/ l), respectively. Plasma ACTH was measured by commercially available immunoradiometric assay kit, ALLEGRO HS$\mathrm{ACTH}^{\mathrm{TM}}$ (Nichols Institute, San Juan Capistrano, CA, USA), with a reference range of $2-11 \mathrm{pmol} / l$. Urinary free cortisol and 17-hydroxycorticosteroids (17OHCS) were measured by Gammacort Cortisol Kit ${ }^{\mathrm{TM}}$ and Porter-Silber's method, with a reference range of $83-276 \mathrm{nmol} /$ day and $2.7-7.3 \mathrm{mg} /$ day, respectively. The method of measuring plasma gastric inhibi-

\footnotetext{
From the Department of Internal Medicine, ${ }^{*}$ Clinical Research Center of Endocrinology and Metabolism, **the Department of Pathology and ***the Department of Surgery, Matsunami General Hospital, Gifu and ****Genetics Division, National Cancer Center Research Institute, Tokyo

Received for publication December 5, 1996; Accepted for publication April 10, 1997

Reprint requests should be addressed to Dr. Noriyoshi Yamakita, the Department of Internal Medicine, Matsunami General Hospital, Kasamatsu, Gifu 501-61
} 
tory polypeptide (GIP) was previously reported elsewhere (3) and its reference range was $167 \pm 12 \mathrm{pg} / \mathrm{ml}$.

\section{Pathological examinations}

Resected adrenals, biopsied specimens of colon, resected colon and autopsied specimens were fixed in $20 \%$ formalin neutral buffer solution and embedded in paraffin. Each three micron-thick section of paraffin-embedded tissués was stained for hematoxylin-eosin and examined light-microscopically.

PCR-SSCP/direct sequencing analysis for the APC gene mutation in the adrenocortical hyperplastic tissue and co-
Ion cancer tissue (Fig. 1a, b)

The APC gene mutation was examined as described (4). Briefly, high molecular weight DNA was extracted by proteinase $\mathrm{K}$ digestion/phenol-chloroform extraction method from the tissues of hyperplastic lesion of the left adrenal gland, the welldifferentiated adenocarcinoma at the rectosigmoid region and the non-tumorous colonal mucosa of the patient. PCR reaction mixture contains 50-100 ng of genomic DNA, $1.0 \mu \mathrm{M}$ each of 2 primers, $0.2 \mathrm{mM}$ each of 4 deoxynucleotide triphosphates, 10 $\mathrm{mM}$ Tris- $\mathrm{HCl} \mathrm{pH} 8.3,50 \mathrm{mM} \mathrm{KCl}, 1.5 \mathrm{mM} \mathrm{MgCl}_{2}, 0.01 \%$ gelatin, 0.125 units of Taq polymerase and $0.2 \mu \mathrm{l}$ of $\left[\alpha^{32} \mathrm{P}\right]$ $(10 \mathrm{mCi})$ in a volume of $0.5 \mu \mathrm{l}$. Seventeen sets of primers were

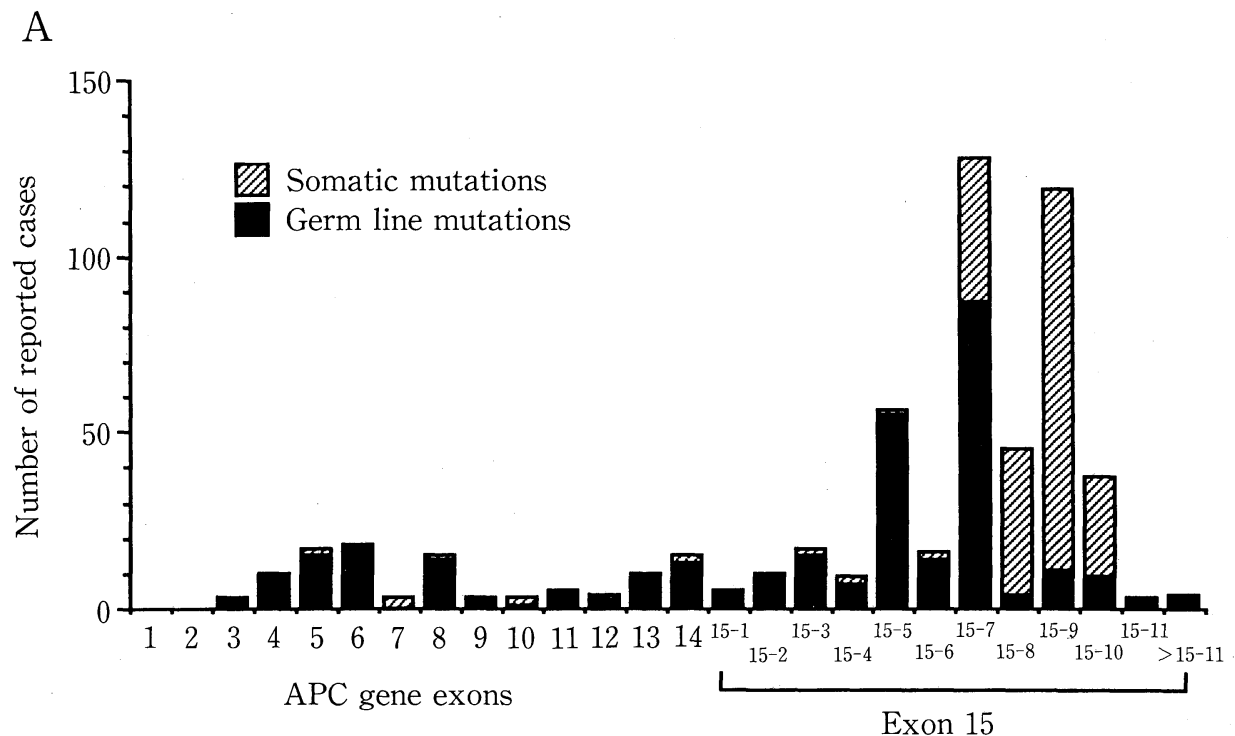

B
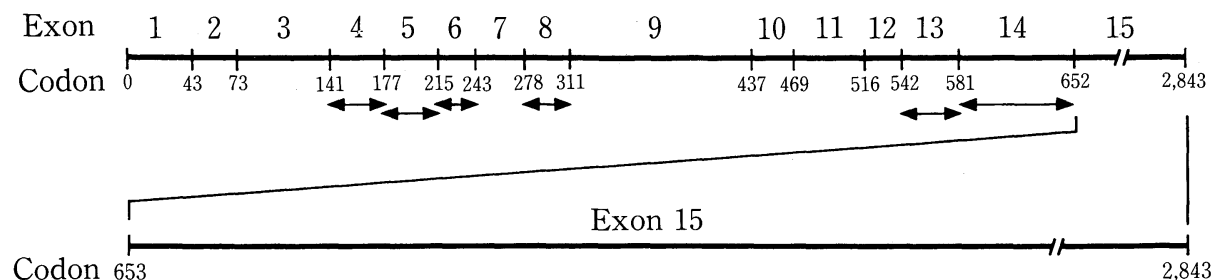

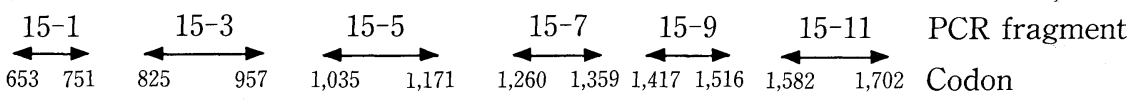

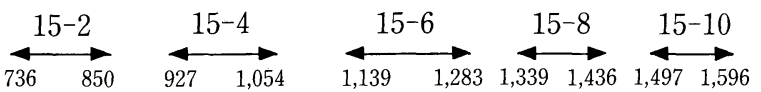

Figure 1. A. Frequency of the APC gene mutations in familial adenomatous polyposis reported in the literature $(4,5,26-51)$. The last and longest exon 15 was divided into 11 PCRsuitable segments from 15-1 to 15-11 and the remaining 3' half of the exon, designated $>15-$ 11. Both the somatic and germ-line mutations were counted. B. Exonic regions analyzed in this study. PCR was targeted to the exonic regions marked by double-head arrows. The primer sequences for exons 4-6, 8, 13 and exon 15 fragments 15-1 to 15-6 were published in ref. (7), exon 14 in ref. (52) and exon 15 fragments 15-7 to 15-10 in ref. (4). The primer set for exon 15 fragment 15-11, 5'-CTGCCATGCCAACAAAGTCA-3' and 5'GAGCCTCATCTGTACTTCTGC-3', was newly designed in this study. 
used in this study, which together analyzed the exons $4,5,6,8$, 13,14 and the amino-terminal half of exon 15 of the human $A P C$ gene. The primers cover $45.5 \%$ of the $A P C$ gene exons, including the mutation cluster region from codon 1,286 to 1,514 (5), and most of the reported somatic and germ-line mutations have been mapped within this region (Fig. 1). The thermal cycles profile was 30 seconds at $94^{\circ} \mathrm{C}, 30$ seconds at $55^{\circ} \mathrm{C}$ and 1 minute at $72^{\circ} \mathrm{C}$ for total 40 cycles. The PCR product was diluted 1:50 in $0.1 \% \mathrm{NaDodSO}_{4}$ and $10 \mathrm{mM}$ EDTA, mixed 1:1 with $95 \%$ formamide dye and applied on a 5\% polyacrylamide gel containing $5 \%$ glycerol. Electrophoresis was performed for 3 hours at $40 \mathrm{~W}$ with the water jacket temperature set at $15^{\circ} \mathrm{C}$. The gel was dried at $80^{\circ} \mathrm{C}$ and exposed to Kodak XAR film at room temperature.

DNA fragments corresponding to the bands on the PCRSSCP analysis were excised from the dried gel and eluted in water (6). The eluted DNA was then PCR-amplified and sequenced by the dideoxy chain termination method using a $5^{\prime}-{ }^{32} \mathrm{P}$ labelled deoxyoligonucleotide as a primer and $\mathrm{Pfu}$ polymerase (dsDNA Cycle Sequencing System, GIBCO, Gaithersburg, MD, USA). The primers used for sequencing were the same as those for the PCR-SSCP. The multiple bands with varying intensity were observed for each DNA sample on the PCR-SSCP gel. They were eluted and sequenced separately.

\section{Case Report}

A 73-year-old male Japanese had been hypertensive for 5 years, which had not been controlled well. During consultation for common cold, he was found to have glucosuria and hypokalemia. Bilateral adrenal enlargement was demonstrated by computed axial tomography (CT). He was referred to Matsunami General Hospital for further examination. On admission, he was $165 \mathrm{~cm}$ in height and weighed $72 \mathrm{~kg}$. Blood pressure was 180/104 mmHg. Truncal obesity, thin skin and bruisability were noticed, but buffalo hump and striae cutis were not seen. Neither spotted nor diffuse pigmentation was noticed. The cardiac ultrasonography findings were unremarkable. Iron deficiency anemia (red blood cell $3.3 \times 10^{12} / l, \mathrm{Hb} 100$ $\mathrm{g} / l, \mathrm{Ht} 0.30, \mathrm{Fe} 6.3 \mu \mathrm{mol} / l)$ was revealed. Serum potassium was slightly low $(3.5 \mathrm{mmol} / l)$, blood urea nitrogen $(11.1 \mathrm{mmol} / \mathrm{l})$ and serum creatinine $(105 \mu \mathrm{mol} / l)$ was high and creatinine clearance was low $(0.54 \mathrm{~mL} / \mathrm{s})$. Plasma glucose level increased from $4.4 \mathrm{mmol} / l$ to $11.4 \mathrm{mmol} / l$ at 90 minutes after oral administration of $75 \mathrm{~g}$ glucose. Basal plasma cortisol level at $0800 \mathrm{~h}$ was high $(632 \mathrm{nmol} / l)$ and showed no diurnal rhythm; 646 at $0900 \mathrm{~h}, 604$ at $2000 \mathrm{~h}$ and 657 at $2100 \mathrm{~h}$. Urinary excretion of free cortisol was also increased to $370 \mathrm{nmol} /$ day. Plasma ACTH was not measurable (less than $1 \mathrm{pmol} / l$ ). Plasma cortisol after overnight-suppression test with $8 \mathrm{mg}$ dexamethasone was $422 \mathrm{nmol} / l$, which was not fully suppressed. By intravenous administration of $100 \mu \mathrm{g}$ corticotropin-releasing hormone $\left(\mathrm{CRH}^{\mathrm{TM}}\right.$, Mitsubishi Chemical, Tokyo), both plasma cortisol and ACTH increased from $524 \mathrm{nmol} / l$ and less than $1 \mathrm{pmol} / l$ to $662 \mathrm{nmol} / l$ and $3 \mathrm{pmol} / l$, respectively. However, these increases were subnormal. Plasma cortisol also increased from
579 to $1,793 \mathrm{nmol} / \mathrm{l}$ by intravenous administration of $250 \mu \mathrm{g}$ 1-24 ACTH (Cortrosyn ${ }^{\mathrm{TM}}$, Daiichi-Seiyaku, Tokyo). During the administration of $3.0 \mathrm{~g}$ metyrapone in 6 divided doses (started from 0400h) daily for 2 days, the patient felt severe fatigue. Accordingly, the final dose of metyrapone at $2400 \mathrm{~h}$ on the 2 nd day was not given. The change of urinary excretion of 17 OHCS during this period was equivocal (baseline, $13.7 \mathrm{mg}$ / day; the $1 \mathrm{st}$ and the 2 nd day of metyrapone administration, 10.0 and $12.3 \mathrm{mg} /$ day, respectively) and plasma ACTH level at 0800h increased from less than 1 to $4 \mathrm{pmol} / l$ on the 2 nd day of metyrapone administration. Only a slightly increased response of plasma cortisol to intravenous administration of argininevasopressin (AVP) (Pitressin ${ }^{\mathrm{TM}}$, Sankyoseiyaku, Tokyo) was shown when $0.1 \mathrm{U}$ AVP was used, from 544 to $627 \mathrm{nmol} / l$, but the increase was clear when $0.2 \mathrm{U}$ was used, from 510 to 742 $\mathrm{nmol} / \mathrm{l}$. In both cases plasma ACTH did not respond at all. Basal plasma DHEA and DHEA-S levels were low, $2.1 \mathrm{nmol} / l$ and 3.6 $\mu \mathrm{mol} / l$, respectively. Plasma GIP and cortisol levels were simultaneously measured before and 2 hours after breakfast for 3 days. Mean value of plasma GIP increased after breakfast from 375 to $825 \mathrm{pg} / \mathrm{ml}$, but that of the plasma cortisol level did not change significantly, from 361 to $348 \mathrm{nmol} / l$. They showed no correlation with each other. On abdominal CT, bilateral adrenal glands were markedly enlarged with multiple large nodules. Bilateral adrenal uptake was demonstrated on ${ }^{131} \mathrm{I}$ iodocholesterol $\left({ }^{131} \mathrm{I}\right.$-Adosterol $\left.{ }^{\mathrm{TM}}\right)$ adrenal scintigraphy even after treatment with $3 \mathrm{mg}$ dexamethasone daily for 7 days. Magnetic resonance imaging (MRI) of the pituitary gland showed no abnormal finding. These data indicated Cushing's syndrome due to AIMAH.

Because of the iron deficiency anemia, colorectal examination was done, which revealed multiple polypoid lesions throughout the colon. At least 21 polyps (from 3 to $45 \mathrm{~mm}$ in diameter, respectively) were found and endoscopic polypectomy was performed for 15 polyps. Well differentiated adenocarcinoma was found in one of them. The two biopsied specimens from the remaining large lesions ( 35 and $45 \mathrm{~mm}$ in diameter) located in the transverse and rectosigmoid colon were also positive for adenocarcinoma.

On January 6, 1995, right adrenalectomy and partial resection of the rectosigmoid and transverse colon were performed. No gross metastasis was found. One to three months after the operation, plasma cortisol level and urinary excretion of free cortisol and 17 OHCS decreased to $248-334 \mathrm{nmol} / l, 141-232$ $\mathrm{nmol} /$ day and $4.9-7.3 \mathrm{mg} / \mathrm{day}$, respectively. However, the plasma ACTH level was still suppressed, being less than 1 $\mathrm{pmol} / \mathrm{l}$. The result of $75 \mathrm{~g}$-oral glucose tolerance test were ameliorated, being from $4.3 \mathrm{mmol} / \mathrm{l}$ to 8.7 at peak in plasma glucose level. Hypertension and hypokalemia were still persistent.

On April 18, 1995, left adrenalectomy was performed. Prednisolone was substituted from the day of the operation and was tapered from $125 \mathrm{mg}$ to $20 \mathrm{mg}$ daily until the 29 th day postoperative. Since discharge on June 2, 1995, the patient required $20 \mathrm{mg} /$ day prednisolone for replacement therapy. In December 1995 , liver metastasis of the colon cancer was suspected on 
abdominal CT. He had a high fever and dyspnea following a low grade fever for about three months and was readmitted in March 1996. However, he died 4 days later. The autopsy revealed liver metastases of colon cancer and, unexpectedly, disseminated tuberculosis involving the lung, pericardium and spleen. The pituitary gland was not investigated on autopsy.

\section{Pathological findings of adrenal glands}

Resected adrenal glands were $6 \times 2 \times 3 \mathrm{~cm}$ and $25 \mathrm{~g}$ in the right gland and $9 \times 5 \times 4 \mathrm{~cm}$ and $65 \mathrm{~g}$ in the left. Histopathologic findings of both glands were similar. Cut sections of the specimens showed multiple, bulging and yellow large nodules. No normal portion of the adrenal glands could be identified macroscopically (Fig. 2). Histologic examination revealed that the nodules were relatively well-circumscribed by thin fibrous septum. Cortical cells in the nodules were composed of cleartype cells and compact-type cells. A variable number of compact-type cells formed a small nest or island-like structure (Fig. 3 ), and extracapsular extension was seen. The normally arranged portion of the cortex was almost lost and the adrenal medulla was thin.

\section{Study on the mutation of APC gene in the adrenocortical hyperplastic tissue and colon cancer tissue}

As shown in Fig. 4A, the PCR-SSCP analysis for the region spanning exon 8 showed an abnormal band on the colorectal cancer specimen. No other SSCP abnormalities were identified in any of the patient's samples examined by the primer set used in this study (data not shown). In general, multiple bands with varying intensities may appear on a PCR-SSCP gel, presumably representing multiple single-strand DNA conformations from both strands of the template DNA. In this particular SSCP gel, shown in Fig. 4A, three major bands were observed for the exon 8 region. Only the top band showed detectable mobility shift for the colon cancer sample. DNAs were eluted separately from all the three bands with or without mobility shift and sequenced by the direct method. All the DNA samples derived from the colon cancer sample showed A to $\mathrm{G}$ transition at the 8 bases upstream of the intron 7 - exon 8 boundary (only one DNA sequence is shown in Fig. 4B). The band corresponding to the normal sequence was not detectable in the colon cancer specimen on the sequencing gel.

On the other hand, the nucleotide sequence of the DNA samples obtained from the adrenal hyperplastic tissue and the non-tumorous colonal mucosa of this patient were identical to those of the control DNA from a normal unrelated subject and also to the published normal sequence on this region (7).

\section{Discussion}

The etiology of AIMAH has not been well-established. Hermus et al (8) and Smals et al (9) proposed the possibility that long-standing ACTH excess induces macronodular adrenocortical hyperplasia. However, based on their observation, patients with bilateral adrenocortical hyperplasia have measurable plasma ACTH and the urinary $17 \mathrm{OHCS}$ excretion increases in

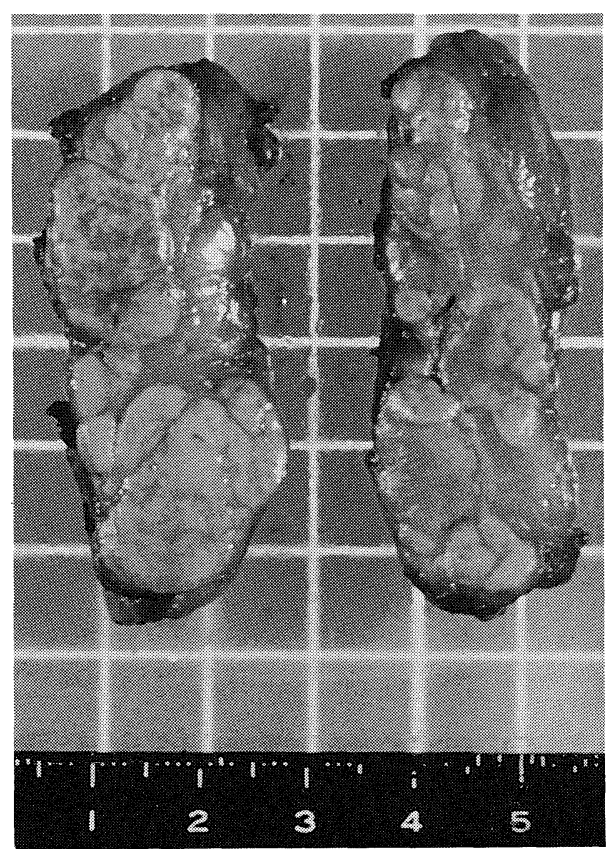

Figure 2. Resected right adrenal gland. Cut sections of the specimen showed multiple, bulging and yellow large nodules. No normal portion of adrenal gland could be identified.

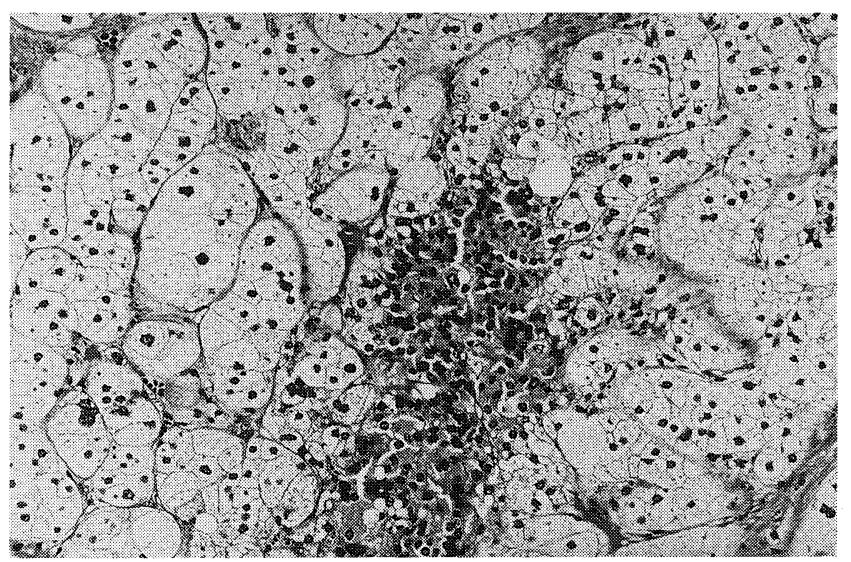

Figure 3. Microscopic findings of adrenocortical nodule (HE stain, $\times \mathbf{2 0 0}$ ). Clear-type cells formed a cord or nest-like structure and some have nuclear pleomorphism. A variable number of compact-type cells formed a small nest or island-like structure.

response to metyrapone (8). In AIMAH, the plasma ACTH level is suppressed and shows no increase after CRH or metyrapone administration (2, 10-12). In the present patient, however, plasma ACTH slightly increased after CRH or metyrapone administration, although subnormal in level. This suggests that the suppression of pituitary ACTH secretion in our patient was not as severe as that observed in $\operatorname{AIMAH}(2,10$ 12). Extremely atrophic adjacent adrenocortical tissue to macro- 


\section{YAMAKITA et al}

A
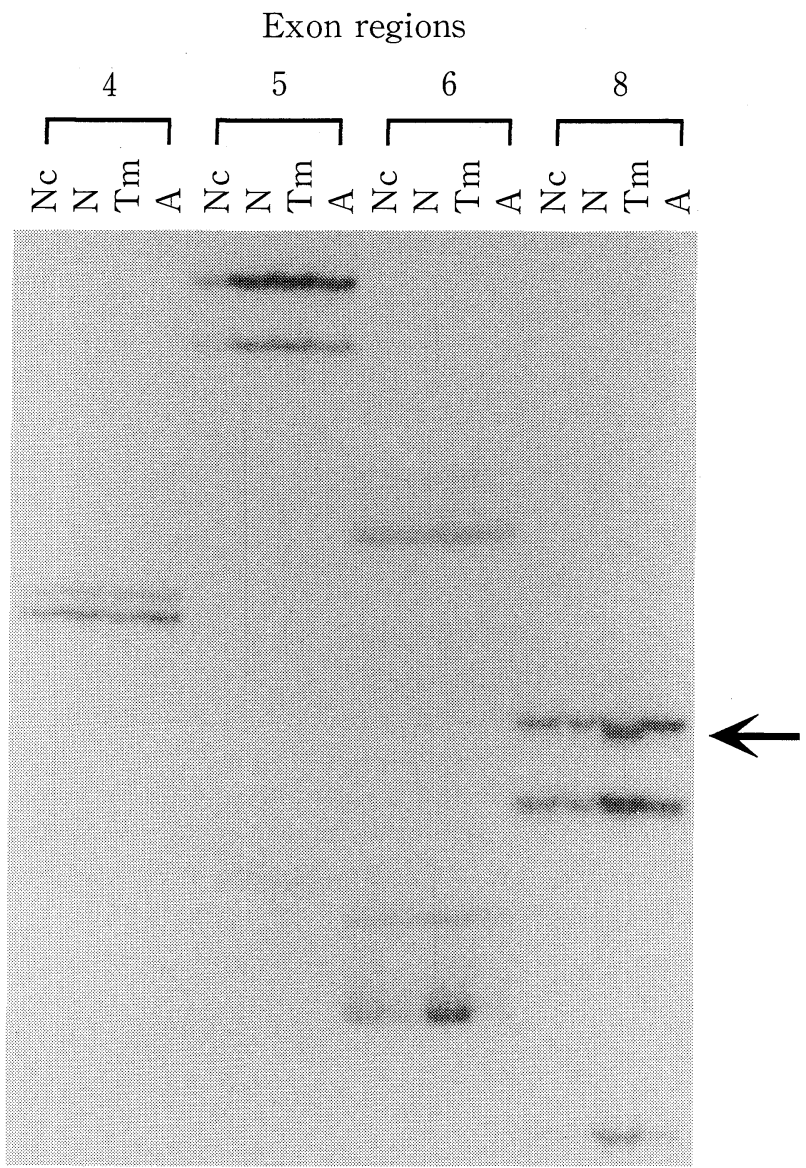

B

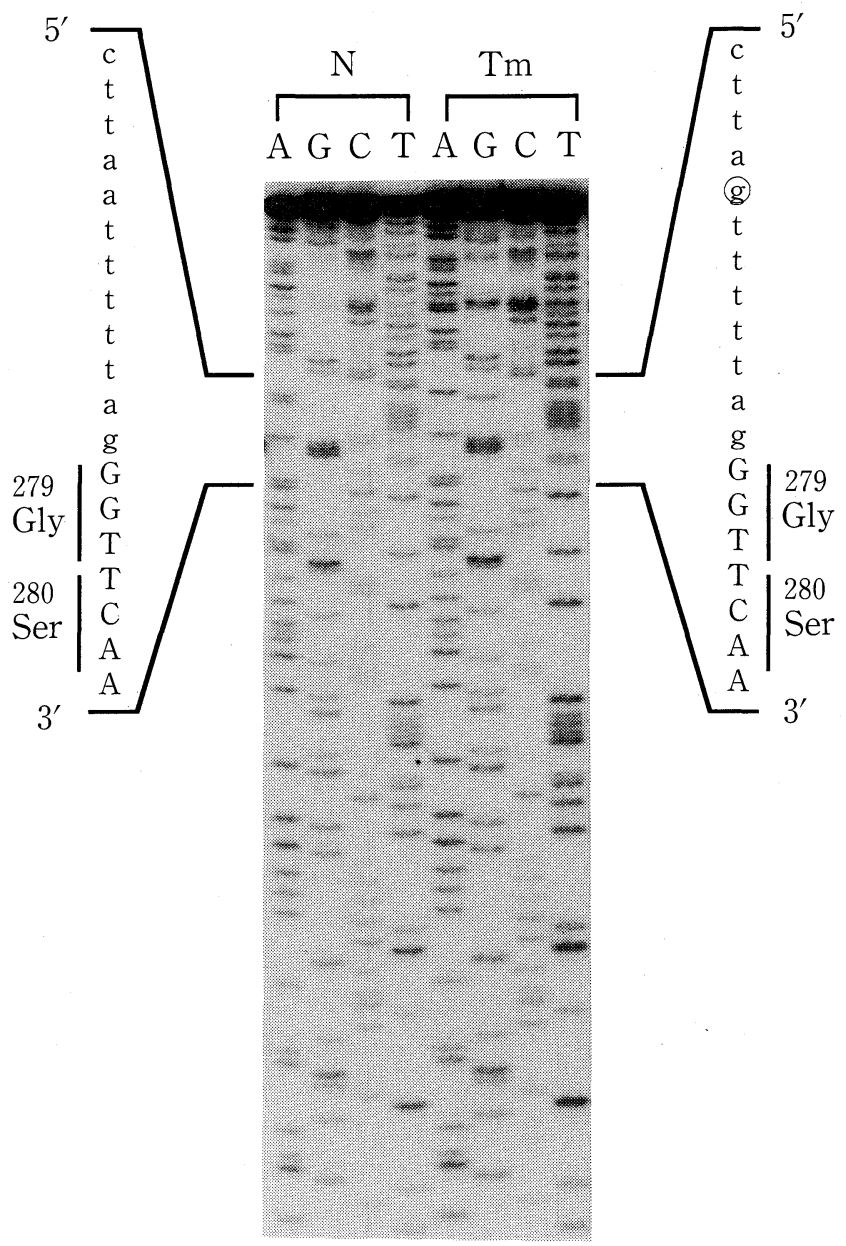

Figure 4. A. PCR-SSCP analysis of the APC gene for the exon 4, 5, 6 and 8 regions. Nc is the normal control DNA from an unrelated subject; $N$, Tm and $A$ are non-tumorous rectal mucosa, colon cancer and adrenal hyperplasia of the patient, respectively. The arrow shows the abnormal band for the colon cancer sample on the exon 8 PCR-SSCP analysis. B. Direct sequencing of the PCR-SSCP band of the exon 8 region. Only $\mathrm{N}$ and Tm samples are shown. The sequence of the Nc and A samples were the same as $\mathrm{N}$, which was identical as the published normal sequence (6). The sequence was confirmed on both strands. The intron sequence is presented in lower case letters and the exon sequence in upper case letters. The $A$ to $G$ point mutation is circled.

nodules and no evidence of pituitary adenoma in AIMAH $(2$, $10-14)$ is not consistent with the hypothesis of Kloppenborg $(8$, 9). An increase of plasma cortisol in response to AVP stimulation was seen in the present patient, similar to other patients with AIMAH as reported by Horiba et al (15). The absence of correlation between plasma cortisol and GIP proved that the hyperplasia in our patient was not GIP-dependent (16). Based on these findings, the clinicopathological characteristics of our patient satisfied the criteria of AIMAH, although the reason why there was incomplete suppression of ACTH secretion remains unclear.

Almost all reported adrenocortical lesions of Cushing's syndrome associated with colorectal adenomatosis were adenoma or carcinoma, but not AIMAH (17-20). The patient with AIMAH reported by Lieberman et al (14) had colon polypec- tomy, with no mention of the number of polyps. One Japanese patient (21) had AIMAH associated with multiple colon polyps. It seems that this rare association seen in this patient (21) and our patient was not incidental. Genetic study of tumorigenesis of colon adenoma/carcinoma is now being explored extensively. Characteristic genetic findings, however, have not been reported in patients with AIMAH. A point mutation of stimulatory guanine nucleotide-binding protein (Gs $\alpha)$ gene in adrenocortical nodular tissue of an infant with Cushing's syndrome due to nodular adrenal hyperplasia was reported (22), similar to McCune-Albright's syndrome (23), although the adrenal lesion was not AIMAH. Activating Gs $\alpha$ mutations in adrenocortical cells could, in theory, lead to cellular proliferation and nodule formation (22). In another report (14), no mutation of Gs $\alpha$ gene in the adrenocortical tissue was found in a patient with 
AIMAH. Unfortunately, we did not examine mutations in Gs $\alpha$ gene in the present patient.

The genetic abnormality responsible for the development of familial adenomatous polyposis was identified as the inactivation of the putative tumor suppressor gene, $A P C$, which stands for adenomatous polyposis coli (24). Loss of normal allele of the $A P C$ gene was reported in an adrenocortical carcinoma tissue from a patient with familial adenomatous polyposis (19). The A to $\mathrm{G}$ transition seen in the splice acceptor site of intron 7 of $A P C$ gene in the colon cancer tissue detected in the present patient was within the polypyrimidine tract of the splice acceptor consensus sequence, $(\mathrm{U} / \mathrm{C})_{11} \mathrm{NCAG}: \mathrm{G}$, the last $\mathrm{G}$ being the first nucleotide of the 3 ' exon (25). The point mutation in the splice acceptor site may affect the normal splicing mechanism of the $A P C$ gene in cancer cells. In our patient, however, a point mutation of $A P C$ gene was found in the colon cancer sample but not in the adrenal hyperplastic tissue. The association of AIMAH with multiple colon adenoma/carcinoma is considered to be incidental, but the possibility that common etiological genetical anomaly other than $A P C$ gene may be present between multiple colon adenomas/carcinomas and hyperplastic adrenal cortex in AIMAH in our patient cannot be disregarded.

Acknowledgements: We appreciate Dr. Hironobu Sasano from Tohoku University for his kind suggestion about the pathological findings of adrenocortical hyperplastic tissue. We also appreciate Dr. Leilani B. Mercado-Asis from University of Santo Tomas in Philippines for reviewing the manuscript. We thank Dr. Ruriko Murai for the treatment of the patient after discharge from our hospital. We also thank Ms. Sumiko Onami and Wakako Yoshimura for their excellent contributions to the $A P C$ gene analysis.

\section{References}

1) Young WF Jr, Carney JA, Musa BU, Wulffraat NM, Lens JW, Drexhage HA. Familial Cushing's syndrome due to primary pigmented nodular adrenocortical disease: Reinvestigation 50 years later. N Engl J Med 321: $1659,1989$.

2) Aiba M, Hirayama A, Iri H, et al. Adrenocorticotropic hormone-independent bilateral adrenocortical macronodular hyperplasia as a distinct subtype of Cushing's syndrome. Enzyme histochemical and ultrastructural study of four cases with a review of the literature. Am J Clin Pathol 96: $334,1991$.

3) Takemura J, Seino Y, Sakurai H, Taminato T, Imura H. Radioimmunoassay of gastric inhibitory polypeptide. Horumon To Rinsho 31: 485, 1983 (in Japanese).

4) Yashima K, Nakamori S, Murakami Y, et al. Mutations of the adenomatous polyposis coli gene in the mutation cluster region: Comparison of human pancreatic and colorectal cancers. Int J Cancer 59: 43, 1994.

5) Miyoshi $Y$, Nagase $H$, Ando H, et al. Somatic mutations of the APC gene in colorectal tumors: mutation cluster region in the APC gene. Hum Mol Genet 1: 229, 1992.

6) Suzuki Y, Sekiya T, Hayashi K. Allele-specific polymerase chain reaction: a method for amplification and sequence determination of a single component among a mixture of sequence variants. Anal Biochem 192: 82, 1991.

7) Groden J, Thliveris A, Samowitz W, et al. Identification and characterization of the familial adenomatous polyposis coli gene. Cell 66: 589, 1991.

8) Hermus AR, Pieters GF, Smals AG, et al. Transition from pituitarydependent to adrenal-dependent Cushing's syndrome. NEngl J Med 318: 966, 1988

9) Smals AG, Pieters GF, Haelst UJ, Kloppenborg PW. Macronodular adrenocortical hyperplasia in long-standing Cushing's disease. J Clin Endocrinol Metab 58: 25, 1984.

10) Sasano H, Suzuki T, NaguraH. ACTH-independent macronodular adrenocortical hyperplasia: Immunohistochemical and in situ hybridization studies of steroidogenic enzymes. Mod Pathol 7: 215, 1994.

11) Malchoff CD, Rosa J, DeBold CR, et al. Adrenocorticotropin-independent bilateral macronodular adrenal hyperplasia: An unusual cause of Cushing's syndrome. J Clin Endocrinol Metab 68: 855, 1989.

12) Demura $H$, Nomura $K$, Naruse $M$, et al. Recent topics of Cushing's syndrome in Japan. Horumon To Rinsho 44: 797, 1996 (in Japanese).

13) Aiba M. Cushing's syndrome due to huge bilateral adrenocortical multinodular hyperplasia - ACTH-independent bilateral adrenocortical macronodular hyperplasia (AIMAH). Nippon Naibunpi Gakkai Zasshi 70: 37, 1994 (Abstract in English).

14) Lieberman SA, Eccleshall TR, Feldman D. ACTH-independent massive bilateral adrenal disease (AIMBAD): A subtype of Cushing's syndrome with major diagnostic and therapeutic implications. Eur J Endocrinol 131: 67, 1994.

15) Horiba N, Suda T, Aiba M, et al. Lysine vasopressin stimulation of cortisol secretion in patients with adrenocorticotropin-independent macronodular adrenal hyperplasia. J Clin Endocrinol Metab 80: 2336, 1995.

16) Reznik Y, Allali-Zerah V, Chayvialle JA, et al. Food-dependent Cushing's syndrome mediated by aberrant adrenal sensitivity to gastric inhibitory polypeptide. N Engl J Med 327: 981, 1992.

17) Ushio K, Ichikawa $H$, Yamada $T$, Sasagawa M. Gastric and duodenal lesions associated with familial polyposis coli. Stomach and Intestine 12: 1547, 1977 (Abstract in English).

18) Painter TA, Jagelman DG. Adrenal adenomas and adrenal carcinomas in association with hereditary adenomatosis of the colon and rectum. Cancer 55: 2001, 1985.

19) Seki M, Tanaka K, Kikuchi-Yanoshita R, et al. Loss of normal allele of the APC gene in an adrenocortical carcinoma from a patient with familial adenomatous polyposis. Hum Genet 89: 298, 1992.

20) Naylor EW, Gardner EJ. Adrenal adenomas in a patient with Gardner's syndrome. Clin Genet 20: 67, 1981.

21) Hayashi Y, Kajino S, Nimura T, Kamiya F, Ookubo K. A case of Cushing's syndrome due to bilateral macronodular adrenocortical hyperplasia associated with multiple colon polyps. Nippon Naibunpi Gakkai Zasshi 69: 728, 1993 (in Japanese).

22) Boston BA, Mandel S, LaFranchi S, Bliziotes M. Activating mutation in the stimulatory guanine nucleotide-binding protein in an infant with Cushing's syndrome and nodular adrenal hyperplasia. J Clin Endocrinol Metab 79: 890, 1994.

23) Weinstein LS, Shenker A, Gejman PV, Merino MJ, Friedman E, Spiegel AM. Activating mutations of the stimulatory $\mathrm{G}$ protein in the McCuneAlbright syndrome. N Engl J Med 325: 1688, 1991.

24) Groden J, Thliveris A, Samowitz W, et al. Identification and characterization of the familial adenomatous polyposis coli gene. Cell 66: 589, 1991.

25) Padgett RA, Grabowski PJ, Konarska MM, Seiler S, Sharp PA. Splicing of messenger RNA precursors. Annu Rev Biochem 55: 1119, 1986.

26) Ando H, Míiyoshi Y, Nagase H, Baba S, Nakamura Y. Detection of 12 germ-line mutations in the adenomatous polyposis coli gene by polymerase chain reaction. Gastroenterology 104: 989, 1993.

27) Cottrell S, Bicknell D, Kaklamanis L, Bodmer WF. Molecular analysis of APC mutations in familial adenomatous polyposis and sporadic colon carcinomas. Lancet 340: 626, 1992.

28) De Benedetti L, Sciallero S, Gismondi V, et al. Association of APC gene mutations and histological characteristics of colorectal adenomas. Cancer Res 54: 3553, 1994.

29) Dobbie Z, Spycher M, Hurliman R, et al. Mutational analysis of the first 14 exons of the adenomatous polyposis coli (APC) gene. Eur J Cancer 30A: 1709, 1994.

30) Fodde R, van der Luijt R, Wijnen J, et al. Eight novel inactivating germ line mutations at the APC gene identified by denaturing gradient gel electrophoresis. Genomics 13: 1162, 1992. 


\section{YAMAKITA et al}

31) Gallinger S, Vivona AA, Odze RD, et al. Somatic APC and K-ras codon 12 mutations in periampullary adenomas and carcinomas from familial adenomatous polyposis patients. Oncogene 10: 1875, 1995.

32) Gayther SA, Wells D, SenGupta SB, et al. Regionally clustered APC mutations are associated with a severe phenotype and occur at a high frequency in new mutation cases of adenomatous polyposis coli. Hum Mol Genet 3: 53, 1994.

33) Gebert JF, Hahn M, Kadmon M, Herfarth C, Schackert HK. Identification of a novel germline mutation in a FAP family. Hum Mol Genet 3: 1167, 1994.

34) Horii A, Nakatsuru S, Miyoshi Y, et al. The APC gene, responsible for familial adenomatous polyposis, is mutated in human gastric cancer. Cancer Res 52: 3231, 1992.

35) Ichii $\mathrm{S}$, Takeda $\mathrm{S}$, Horii $\mathrm{A}$, et al. Detailed analysis of genetic alterations in colorectal tumors from patients with and without familial adenomatous polyposis (FAP). Oncogene 8: 2399, 1993.

36) Miyaki M, Konishi M, Kikuchi-Yanoshita R, et al. Characteristics of somatic mutation of the adenomatous polyposis coli gene in colorectal tumors. Cancer Res 54: 3011, 1994.

37) Nagase H, Miyoshi $Y$, Horii A, et al. Correlation between the location of germ-line mutations in the APC gene and the number of colorectal polyps in familial adenomatous polyposis patients. Cancer Res 52: 4055, 1992.

38) Nishisho I, Nakamura Y, Miyoshi $Y$, et al. Mutations of chromosome 5q21 genes in FAP and colorectal cancer patients. Science 253: 665, 1991.

39) Park JG, Han HJ, Kang MS, Nakamura Y. Presymptomatic diagnosis of familial adenomatous polyposis coli. Dis Colon Rectum 37: 700, 1994.

40) Petersen GM, Francomano C, Kinzler K, Nakamura Y. Presymptomatic direct detection of adenomatous polyposis coli (APC) gene mutations in familial adenomatous polyposis. Hum Genet 91: 307, 1993.

41) Powell SM, Zilz N, Beazer-Barclay Y, et al. APC mutations occur early during colorectal tumorigenesis. Nature 359: 235, 1992.

42) Prosser J, Condie A, Wright M, et al. APC mutation analysis by chemical cleavage of mismatch and a protein truncation assay in familial adenomatous polyposis. Br J Cancer 70: 841, 1994.

43) Smith AJ, Stern HS, Penner M, et al. Somatic APC and K-ras codon 12 mutations in aberrant crypt foci from human colons. Cancer Res 54: 5527, 1994.

44) Stella A, Lonoce A, Resta N, et al. Familial adenomatous polyposis: identification of a new frameshift mutation of the APC gene in an Italian family. Biochem Biophys Res Commun 184: 1357, 1992.

45) Stella A, Montera M, Resta N, et al. Four novel mutations of the APC (adenomatous polyposis coli) gene in FAP patients. Hum Mol Genet 3: 1687, 1994 (published erratum appears in Hum Mol Genet 3: 1918, 1994).

46) Tahara E. Molecular mechanism of stomach carcinogenesis. J Cancer Res Clin Oncol 119: 265, 1993 [editorial].

47) Tamura G, Maesawa C, Suzuki Y, et al. Mutations of the APC gene occur during early stages of gastric adenoma development. Cancer Res 54: 1149, 1994.

48) Toyooka M, Konishi M, Kikuchi-Yanoshita R, Iwama T, Miyaki M. Somatic mutations of the adenomatous polyposis coli gene in gastroduodenal tumors from patients with familial adenomatous polyposis. Cancer Res 55: 3165, 1995.

49) Uzawa K, Yoshida H, Suzuki H, et al. Abnormalities of the adenomatous polyposis coli gene in human oral squamous-cell carcinoma. Int J Cancer 58: 814, 1994.

50) Varesco L, Gismondi V, James R, et al. Identification of APC gene mutations in Italian adenomatous polyposis coli patients by PCR-SSCP analysis. Am J Hum Genet 52: 280, 1993.

51) Wallis YL, Macdonald F, Hulten M, et al. Genotype-phenotype correlation between position of constitutional APC gene mutation and CHRPE expression in familial adenomatous polyposis. Hum Genet 94: 543, 1994.

52) Miyoshi $Y$, Ando $H$, Nagase $H$, et al. Germ-line mutations of the APC gene in 53 familial adenomatous polyposis patients. Proc Natl Acad Sci USA 89: 4452, 1992. 